\title{
Digoxigenin-Labeled Peptides for the Immuno- logical Quantification of Intracellular Signaling Proteins: Application to the MAP Kinase Kinase Isoform MEK2
}

BioTechniques 23:1098-1103 (December 1997)

\author{
Charles Blais, Jr., Guy Dra- \\ peau ${ }^{1}$, Sylvain Meloche ${ }^{2}$, \\ Réjean Morais ${ }^{3}$ and Albert \\ Adam \\ Université de Montréal, Mon- \\ tréal, ${ }^{1}$ Hôtel-Dieu de Québec, \\ Québec, ${ }^{2}$ Hôtel-Dieu de Mon- \\ tréal, Montréal, ${ }^{3}$ Université de \\ Montréal, Montréal, QC, Canada
}

\section{INTRODUCTION}

Digoxigenin (Dig) is the steroidal aglycone of a cardiac glycoside, digoxin, extracted from Digitalis lanata. Different derivatives of Dig have been synthesized. Although labeling of DNA probes and antibodies constitutes the first purpose of these compounds (13), new interesting applications such as the labeling of haptens have been recently described. When combined with enzyme-conjugated anti-Dig antibodies, Dig-labeled tracers have allowed the development of highly sensitive and specific competitive enzyme immunoassays (EIAs) for the quantification of peptides or drugs present at the picomolar concentration in biological samples $(1,9,18)$.

The mitogen-activated protein (MAP) kinase cascade is a major signaling module by which cells transduce extracellular stimuli into intracellular responses. This enzymatic cascade is characterized by a series of three sequentially acting protein kinases comprising a MAP kinase kinase kinase, a MAP kinase kinase and the MAP kinase itself (for review, see References 5, 6 and 19). Three distinct MAP kinase cascades have been characterized in mammalian cells. The prototype of these cascades is the one leading to activation of the MAP kinases ERK1 (extracellular signal-regulated kinase 1) and ERK2, which is associated with the regulation of cell proliferation and differentiation (14). ERK1 and ERK2 are activated by phosphorylation on threo- nine and tyrosine residues catalyzed by the dual-specificity enzyme MEK (MAP kinase kinase), which is in turn activated by serine phosphorylation by one of several MAP kinase kinase kinase such as Raf-1, B-Raf and Mos. Two closely related isoforms of MEK, MEK1 and MEK2, have been described that differ mainly in their amino-terminal region and in a proline-rich region located between subdomains IX and $X$ of the kinasic domain $(4,20,21)$.

In light of the importance of this cascade in cell proliferation and differentiation and its possible involvement in the pathogenesis of growth-associated diseases, it becomes important to develop sensitive and reliable assays to measure the expression of the various components of the cascade in biological tissues. So far, the expression of these protein kinases in cell lysates has been examined by immunoblot analyses, which allow at best a semiquantitative assessment of the protein abundance. In this paper, we describe, to our knowledge, for the first time the development of competitive EIAs for the quantification of an enzyme of the MAP kinase cascade in cell lysates. Polyclonal antibodies were raised in rabbits against the amino-terminal and proline-rich amino acid sequences of MEK2. These specific polyclonal IgGs in combination with Dig-labeled peptides allowed the set up of two competitive immunoassays. These assays were analytically validated and applied to the quantification of immunoreactive MEK2 in different cell lines. 


\section{MATERIALS AND METHODS}

\section{Materials}

Dimethylformamide was purchased from Anachemia (Montréal, QC, Canada). PD-10 Columns and Protein GSepharose $^{\circledR}$ 4B (MAbTrap ${ }^{\circledR}$ G) were obtained from Pharmacia Biotech (Uppsala, Sweden), and horseradish peroxidase (HRP)-labeled Fab fragments anti-digoxigenin and digoxigenin-3-Omethylcarbonyl- $\varepsilon$-aminocaproic acid$N$-hydroxysuccinimide ester (DIG-O$\mathrm{Su})$ were from Boehringer Mannheim (Mannheim, Germany). $N$-methylmorpholine, Tris-base, Tris- $\mathrm{HCl}$, Tween ${ }^{\circledR}$ 20, o-phenylenediamine dihydrochloride, urea peroxide and complete and incomplete Freund adjuvants were purchased from Sigma Chemical (St. Louis, MO, USA). Keyhole limpet hemocyanin (KLH) and trifluoroacetic acid (TFA) were from Pierce Chemical (Rockford, IL, USA). The $\mathrm{C}_{18}$ column was from Vydac (Hesperia, CA, USA) and 1-hydroxybenzotriazole from Aldrich Chemical (Milwaukee, WI, USA). Acetonitrile (HPLC grade) and all other reagents (analytical grade) unless specified otherwise were purchased from Fisher Scientific (Montréal, QC, Canada). The analytical HPLC system equipped with a UV detector was obtained from Waters (Milford, MA, USA). A SpeedVac ${ }^{\circledR}$ Vacuum Concentrator was from Savant Instruments (Holbrook, NY, USA), and immunoplates $\mathrm{A} / \mathrm{C}$ Nunc were from Nalge Nunc International (Roskilde, Denmark). A Behring ELISA Processor (Behring Institute, Marburg, Germany) was used for the EIA steps.

\section{Synthesis of the Immunogen}

The following peptides, Cys-AlaGlu-Gly-Pro-Ser-Pro-Thr-Ser-Glu-GlyAla (peptide 1; mol wt 1105.16) and Cys-Aca-Glu-Gly-Glu-Pro-His-Ser-IleSer- $\mathrm{NH}_{2}$ (peptide 2; mol wt 1070.21), containing amino acid sequences of the amino-terminal and proline-rich regions of MEK2, respectively, were synthesized by solid-phase chemistry using previously outlined methods (10). These haptens were coupled with maleimide-activated KLH. Briefly, each peptide $(10 \mathrm{mg})$ was dissolved in $500 \mu \mathrm{L}$ of $0.1 \mathrm{M}$ sodium phosphate buffer, pH 7.2. This solution was combined with $10 \mathrm{mg}$ of the maleimide-derivatized KLH dissolved in $1 \mathrm{~mL}$ of distilled water. The reaction was allowed to react for $2 \mathrm{~h}$ at room temperature (RT). The conjugate was purified by gel filtration on a PD-10 Column equilibrated with the sodium phosphate buffer. Before lyophilization, the protein content of the eluate was quantified using the BCA Protein Assay Kit (Pierce Chemical) using bovine serum albumin (BSA) as standard.

\section{Production and Purification of Anti- bodies Against Amino-Terminal and Proline-Rich Peptides}

Five rabbits ("Fauve de Bourgogne" strain; Centre de Diagnostic Hormonal, Marloie, Belgium) were immunized with $100 \mu \mathrm{g}$ of either immunogen described above, dissolved in the total Freund adjuvant $(1 \mathrm{~mL})$. After six boostings (immunogen $[100 \mu \mathrm{g}]$ dissolved in $500 \mu \mathrm{L}$ of the incomplete Freund adjuvant), antisera were collected. Polyclonal IgGs were purified by protein $\mathrm{G}$ affinity chromatography using a MAbTrap $G$ kit according to the instructions of the manufacturer (Pharmacia Biotech). The concentration of the purified material was measured by its absorption at $278 \mathrm{~nm}$. The purity was checked using the 278/252-nm ratio (17). The presence of specific polyclonal IgGs was screened by a classical experimental procedure using successive dilutions of polyclonal IgGs and Diglabeled peptides as tracers (8). The different incubation and revelation steps were performed as described below.

\section{Specificity of the Anti-Amino-Ter- minal and Anti-Proline-Rich Peptide Antisera}

The specificity of both antisera was tested using HeLa cell extracts. Confluent cells were washed twice with icecold, phosphate-buffered saline (PBS) and lysed in Triton ${ }^{\circledR} \mathrm{X}-100$ lysis buffer (50 mM Tris- $\mathrm{HCl}, \mathrm{pH} 7.4,100 \mathrm{mM}$ $\mathrm{NaCl}, 50 \mathrm{mM} \mathrm{NaF}, 5 \mathrm{mM}$ EDTA, 40 $\mathrm{mM} \beta$-glycerophosphate, $1 \mathrm{mM}$ sodium orthovanadate, $10^{-4} \mathrm{M}$ phenylmethylsulfonyl fluoride [PMSF], 10-6 M leupeptin, $10^{-6} \mathrm{M}$ pepstatin A, $1 \%$ Triton X-100) for $30 \mathrm{~min}$ at $4^{\circ} \mathrm{C}$. Lysates were clarified by centrifugation at $13000 \times g$ for $10 \mathrm{~min}$. Equal amounts of lysate proteins $(400-500 \mu \mathrm{g})$ in $\mathrm{ab}$ sence and in presence of an excess of the amino-terminal or proline-rich peptide were incubated for $4 \mathrm{~h}$ at $4{ }^{\circ} \mathrm{C}$ with $10 \mu \mathrm{L}$ of the indicated MEK2 antibodies pre-adsorbed to protein A-Sepharose beads. Immune complexes were washed three times in Triton X-100 lysis buffer. The proteins were eluted by heating at $95^{\circ} \mathrm{C}$ for $5 \mathrm{~min}$ in Laemmli sample buffer, resolved by sodium dodecyl sulfate (SDS)-gel electrophoresis on $10 \%$ acrylamide gels and transferred to Hybond ${ }^{\circledR}-\mathrm{C}$ Nitrocellulose Membranes (Amersham, Arlington Heights, IL, USA) in $25 \mathrm{mM}$ Tris, $192 \mathrm{mM}$ glycine. The membrane was blocked for $1 \mathrm{~h}$ at $37^{\circ} \mathrm{C}$ in TBST (20 mM Tris- $\mathrm{HCl}$, $\mathrm{pH} 7.4,137 \mathrm{mM} \mathrm{NaCl}, 0.1 \%$ Tween 20) containing 5\% BSA and then incubated for $2 \mathrm{~h}$ with anti-MEK2 monoclonal antibody (Transduction Laboratories, Lexington, KY, USA) diluted 1:500 in blocking solution. The membrane was washed 5 times for $5 \mathrm{~min}$ with TBST before incubation for $1 \mathrm{~h}$ with HRP-conjugated goat anti-mouse IgGs (Bio-Rad, Hercules, CA, USA) diluted 1:10000 in TBST containing $5 \%$ nonfat dry milk. After washing as above, the immunoreactive bands were visualized by enhanced chemiluminescence (ECL ${ }^{\mathrm{TM}}$; Amersham).

\section{Dig-Labeling of Amino-Terminal and Proline-Rich Peptides}

Dig-labeled peptides were synthesized using a similar approach to that previously described for bradykinin (9). Briefly, the DIG-O-Su reagent (5 $\mathrm{mg}$ ) was added to the amino-terminal or proline-rich peptide $(16 \mathrm{mg})$ dissolved in $5 \mathrm{~mL}$ of dimethylformamide (pH adjusted to 9.0 with $N$-methylmorpholine). 1-Hydroxybenzotriazole (1.5 $\mathrm{mg}$ ) was added to the mixture, and the reaction was monitored by analytical HPLC. Monitoring of the coupling reaction was achieved with a Vydac 10$\mu \mathrm{m}(3.9 \times 300 \mathrm{~mm})$ Reverse-Phase $\mathrm{C}_{18}$ Column using a linear gradient of $5 \%-$ $65 \%$ acetonitrile/TFA $0.05 \% /$ water at 2 $\mathrm{mL} / \mathrm{min}$ over a period of $20 \mathrm{~min}$; the absorbance was measured at $214 \mathrm{~nm}$.

After $5 \mathrm{~h}$ at RT, the reaction mixture was then loaded on a Michel-Miller column $(22 \times 130 \mathrm{~mm})$ packed with a 
15-20- $\mu \mathrm{m}$ Reversed-Phase $\mathrm{C}_{18}$ Resin (Vydac) pre-equilibrated with $0.05 \%$ TFA/water. The separation of the derivatized peptide was achieved with a linear gradient of 5\%-70\% acetonitrile/TFA $0.05 \% /$ water. The total volume of eluent was $600 \mathrm{~mL}$ pumped through the column at a rate of 6.5 $\mathrm{mL} / \mathrm{min}$ and collected in fractions of 6-8 mL. Fractions containing the pure Dig-labeled peptide were pooled and lyophilized. Purity of the final product was evaluated by analytical HPLC, and its identity was confirmed by mass spectrometry.

\section{Competitive Enzyme Immunoassays of MEK2}

Unless otherwise mentioned, all washing, dilution and incubation steps were performed in the same incubation buffer: $50 \mathrm{mM}$ Tris- $\mathrm{HCl}, \mathrm{pH} 7.4$, containing $100 \mathrm{mM} \mathrm{NaCl}$ and $0.5 \mathrm{~mL} / \mathrm{L}$ Tween 20. Nunc-Immuno ${ }^{\mathrm{TM}}$ Modules 96-well plates (Nalge Nunc International) were coated overnight at $4^{\circ} \mathrm{C}$ with $100 \mathrm{ng}$ (anti-proline-rich antiserum) or $250 \mathrm{ng}$ (anti-amino-terminal antiserum) of purified polyclonal IgGs (100 $\mu \mathrm{L} /$ well) diluted in the coating buffer (carbonate $100 \mathrm{mM}, \mathrm{pH}$ 9.2). After a 5-wash cycle, the plates were saturated $\left(2 \mathrm{~h}\right.$ at $\left.37^{\circ} \mathrm{C}\right)$ with the incubation buffer $(200 \mu \mathrm{L} /$ well $)$. After a new washing cycle, the plates were incubat-

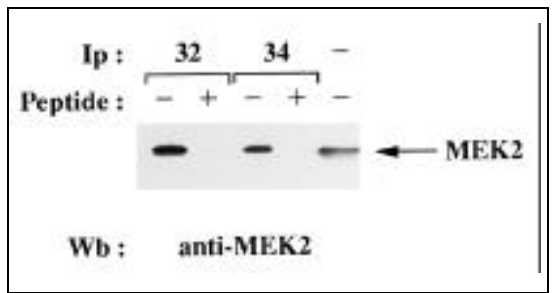

Figure 1. Specificity of antibodies raised against the proline-rich (Ab32) and the aminoterminal (Ab34) amino acid sequences of MEK2. HeLa cell lysates were incubated (Ip: immunoprecipitation) at $4^{\circ} \mathrm{C}$ for $4 \mathrm{~h}$ with $\mathrm{Ab} 32$ or Ab34 pre-adsorbed to protein A-Sepharose beads. The specificity of the antibodies was assessed by preincubation without (-) or with $(+)$ excess antigenic peptides (peptide 2 and peptide 1 , respectively) at a final concentration of $50 \mu \mathrm{M}$. Proteins from total lysate (Ip-) and immunoprecipitates were resolved on a $10 \%$ acrylamide gel and transferred to a nitrocellulose membrane. The membrane was probed with an anti-MEK2 monoclonal antibody (Wb: anti-MEK2) and the proteins visualized by chemiluminescence detection. The position of MEK2 is indicated by an arrow. ed with $100 \mu \mathrm{L}$ of a solution containing $50 \mu \mathrm{L}$ of the corresponding peptide standard or the diluted biological sample and $50 \mu \mathrm{L}$ of the diluted Dig-labeled tracer. The competitive immunoextraction step was obtained by an incubation of $15 \mathrm{~h}$ at $4^{\circ} \mathrm{C}$ under agitation. The unbound material was removed by a new washing cycle. The bound Dig-tracer was then reacted with anti-Dig Fab fragments labeled with $\operatorname{HRP}\left(2 \mathrm{~h}\right.$ at $37^{\circ} \mathrm{C}$ under agitation). Finally, the presence of immune complexes was revealed by the HRP activity. The latter was measured using 100 $\mu \mathrm{L}$ of substrate buffer $(1 \mathrm{mg} / \mathrm{mL}$ of $o$ phenylenediamine dihydrochloride in citrate buffer $\mathrm{pH} 5.0$ with $1 \mathrm{mg} / \mathrm{mL}$ of urea peroxide) per well. After a final incubation of $30 \mathrm{~min}$ in the dark at RT, absorbances were read with the Behring ELISA Processor at $450 \mathrm{~nm}$ using $650 \mathrm{~nm}$ as a reference wavelength. All results (calibration curve and MEK2 concentration) are expressed as mean \pm standard deviation (SD).

\section{Quantification of MEK2 in Different Cell Lines}

MEK2 was quantified in seven cell lines. Five human cell lines, HeLa (A), HL-60 (B), MCF7 (C), U-937 (D) and SCC-13 (E), were obtained from ATCC (Rockville, MD, USA). Two chicken cell lines: DU24 (F), a subclone of chicken DU249 hepatocyte cell line, and DUS3 (G), a mtDNA-less DU24 cell line, were obtained as described earlier (15). All cells were grown under recommended culture conditions.

At confluence, cells were washed with cold PBS and harvested by scraping in RIPA buffer $(50 \mathrm{mM}$ Tris- $\mathrm{HCl}$, $\mathrm{pH} 7.4,1.0 \%$ Nonidet $^{\circledR}$ P-40, $0.25 \%$ NaDOC, 150 mM NaCl, 1 mM EGTA) containing $1 \mathrm{mM}$ PMSF, $5 \mu \mathrm{g} / \mathrm{mL}$ each of aprotinin, leupeptin and pepstatin, 1 $\mathrm{mM} \mathrm{Na} \mathrm{VO}_{3}$ and $1 \mathrm{mM} \mathrm{NaF}$. Lysates were centrifuged at $40000 \times g$ for 30 min, and clear supernatants were collected. Protein content in supernatants was determined according to the method of Lowry as modified for the DC Protein Assay (Bio-Rad) with BSA as standard. For the human cell lines, the amount of immunoreactive MEK2 was also assessed by immunoblot analysis as described above. In this case, 50$100 \mu \mathrm{g}$ of the cell lysates were loaded on the gel.

\section{RESULTS}

\section{Specificity of the Anti-MEK2 Poly- clonal Antibodies Ab32 and Ab34}

To test the specificity of anti-MEK2 antibodies, cellular extracts from HeLa

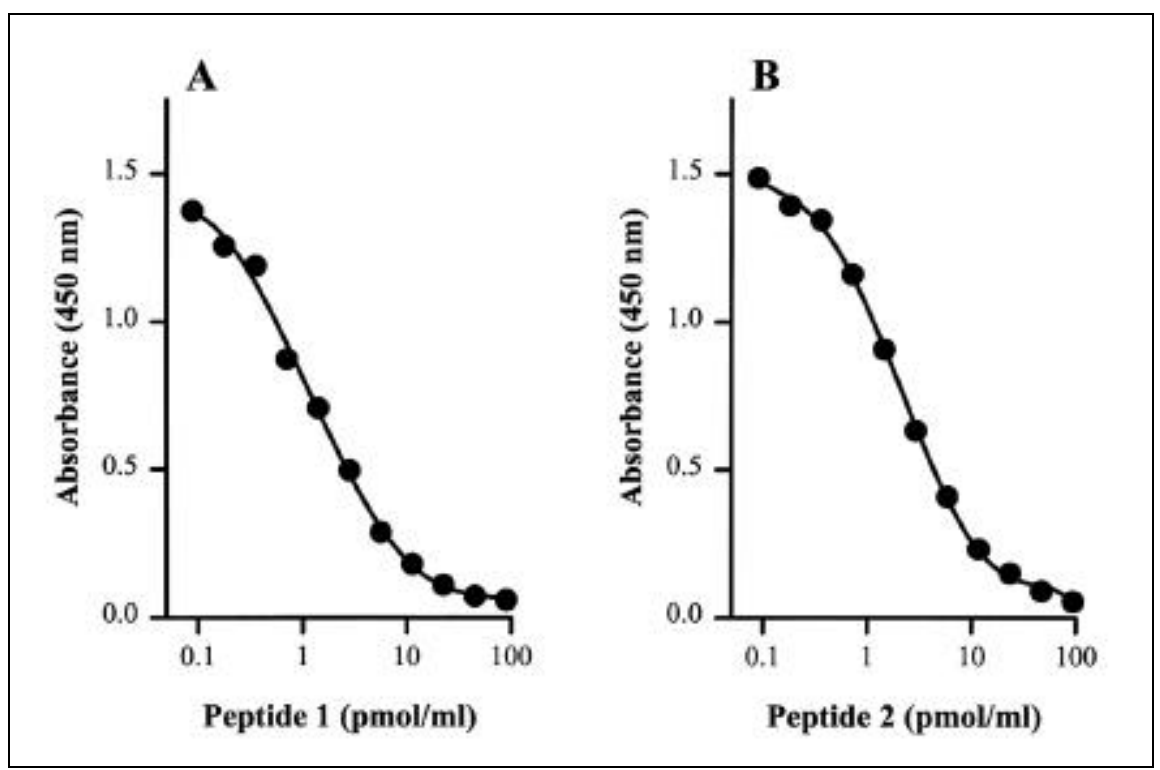

Figure 2. Typical calibration curves of the two competitive EIAs for the quantification of MEK2. The data were obtained using the amino-terminal (A) and the proline-rich (B) peptide as standard and the corresponding Dig-peptide as tracer. 
Table 1. Concentrations of Immunoreactive MEK2 Measured by the Proline-Rich EIA in Seven Different Cell Lines

\begin{tabular}{|lll|}
\hline & Cell lines & $\begin{array}{c}\text { MEK2 } \\
\text { (pmol/mg } \\
\text { of proteins) }\end{array}$ \\
\hline A: & HeLa & $2.53 \pm 0.29$ \\
B: & U-937 & $2.62 \pm 0.13$ \\
C: & SSC-13 & $5.95 \pm 1.22$ \\
D: & MCF7 & $3.88 \pm 0.34$ \\
E: & HL-60 & $0.65 \pm 0.13$ \\
F: & DU24 & $1.19 \pm 0.02$ \\
G: & DUS3 & $0.79 \pm 0.06$ \\
Values are expressed as means \pm \\
SD of triplicate measurements.
\end{tabular}

cells were subjected to immunoprecipitation with antibodies Ab32 and Ab34 (raised against proline-rich and aminoterminal sequences, respectively) and analyzed by immunoblotting using a commercial MEK2 monoclonal antibody. Figure 1 shows that both antibodies specifically precipitated a single band of $46 \mathrm{kDa}$ corresponding to MEK2. Preincubation of the antibodies with an excess of the corresponding immunogenic peptide completely abolished the immunoprecipitation of the MEK2 protein. No reactivity was detected towards other MEK isoforms (data not shown).

\section{Analytical Characteristics of the Competitive EIAs of MEK2}

Figure 2A shows a typical calibration curve obtained for the aminoterminal peptide. For concentrations ranging from $0.088-90.5 \mathrm{pmol} / \mathrm{mL}$, the calibration curve is characterized by a minimal detection limit $\left(\mathrm{B}_{\mathrm{o}}\right.$ minus 2 $\mathrm{SD}$ ) of $63 \pm 18 \mathrm{fmol} / \mathrm{mL}$, a half-maximal saturation value of $1320 \pm 40 \mathrm{fmol} /$ $\mathrm{mL}$ and a slope factor of $-1.002 \pm 0.002$.

The range of concentrations of the proline-rich peptide used for the set up of the analytical assay varied between 0.091-93.4 $\mathrm{pmol} / \mathrm{mL}$ (Figure 2B). The calibration curve is characterized by a minimal detection limit concentration of $71 \pm 17 \mathrm{fmol} / \mathrm{mL}$, a half-maximal saturation value of $1780 \pm 30 \mathrm{fmol} / \mathrm{mL}$ and a slope factor of $-1.004 \pm 0.003$.

\section{Analytical Validation of the Competitive EIAs of MEK2}

The displacement curve obtained with successive dilutions (1:1 to 1:64) of HeLa cell extracts runs parallel to the calibration curve obtained with the amino-terminal (mean slope factor, -1.024) and proline-rich (mean slope factor, -1.002) peptide (Figure 3, A and $\mathrm{B}$, respectively).

Intra- and inter-assay precision of both assays was assessed by testing three diluted HeLa cells extracts

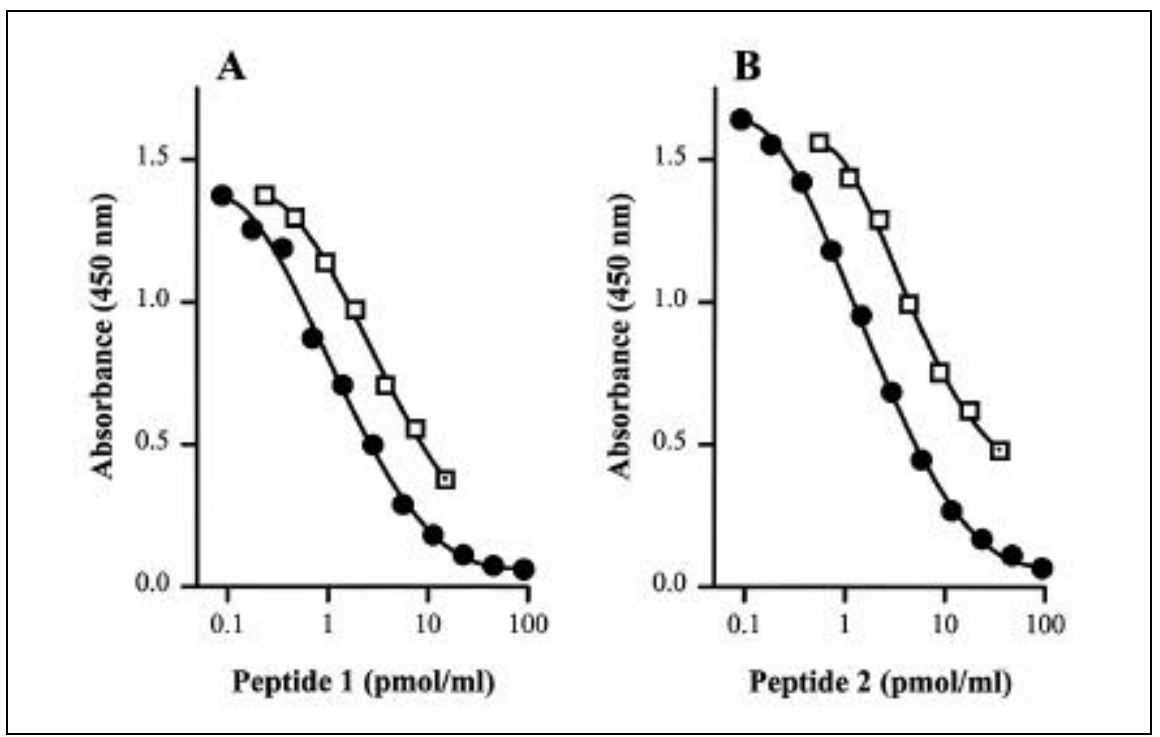

Figure 3. Typical competition curves obtained with successive dilutions of HeLa cell extracts. The displacement curves of HeLa cell extracts $(\square)$ are parallel to the calibration curve $(\bullet)$ of amino-terminal (A) and proline-rich (B) EIAs. 
containing 4.70, 2.25 and $1.25 \mathrm{pmol} /$ $\mathrm{mL}$, respectively, of immunoreactive MEK2. The samples were analyzed in five replicates over five different plates. The intra-assay coefficients of variation (CVs) for the amino-terminal peptide EIA were $3.2 \%, 4.2 \%$ and $4.8 \%$, respectively, and the inter-assay CVs were $5.6 \%, 6.2 \%$ and $4.9 \%$, respectively. For the proline-rich peptide EIA, the intra-assay CVs equaled 3.5\%, $4.9 \%$ and $6.0 \%$, respectively, and the interassay CVs were $7.1 \%, 12.2 \%$ and $8.9 \%$, respectively.

\section{Quantification of MEK2 in Different Cell Lines}

Immunoreactive MEK2 was quantified by both EIAs in different cell lines (A-G). Table 1 presents the mean concentration values measured for MEK2 in these cell lines using the proline-rich EIA. As shown in Figure 4, these values correlate $(r=0.992)$ with those measured in the amino-terminal system.

Finally, the concentrations of MEK2 measured with the amino-terminal EIA in human cell lines could be related with the expression level of the protein detected by immunoblot analysis using a commercially available monoclonal antibody (Figure 5).

\section{DISCUSSION}

The present study described, to our knowledge, for the first time, the development of an EIA for the quantification of an intracellular signaling enzyme, the MAP kinase kinase MEK2. The selection of amino-terminal and prolinerich sequences specific of MEK2 coupled covalently with KLH allowed the production of polyclonal antibodies in rabbits. When tested on cellular extracts, both antisera specifically recognized the native MEK2 protein and were therefore used for EIAs.

Although the Dig-anti-Dig system represents only one of several analytical alternatives to radioisotopic labeling, it possesses however an important advantage when compared with enzyme or biotin labeling. Due to its phytochemical origin, Dig avoids nonspecific binding and allows low detection limit. For these reasons and the intra- cellular localization of MEK2, the Diganti-Dig system was chosen for the set up of the EIAs. The Dig-anti-Dig system is responsible for the high sensitivity of both assays. Moreover, as we have previously shown, this analytical approach does not modify the immunoreactivity of the haptenic structure $(1,9,18)$.

The high sensitivity of the developed methods is compatible with the intracellular concentration of MEK2, allowing a direct quantification of the protein in cell lysates. The parallelism between the calibration curve and the displacement curve obtained with serial dilutions of cell lysates confirms the specificity of both competititve EIAs. In fact, such an analytical approach using competition between a haptenic tracer and a macromolecule has been used for other proteins without any immunogenicity difference between the two chemical species $(2,12)$.

Very similar concentrations of MEK2 were measured by the two EIA systems in a series of cell lines. These observations argue for an equal immunoreactivity of both epitopes in the native enzyme. Importantly, the concentration of MEK2 measured by EIA was well in the range of the enzyme estimated by the semiquantitative immunoblot analysis. Thus, the EIAs developed here provide a rapid and sensitive assay for the quantitative measurement of MEK2 abundance in biological samples. Such an assay could be used, for instance, to study the regula-

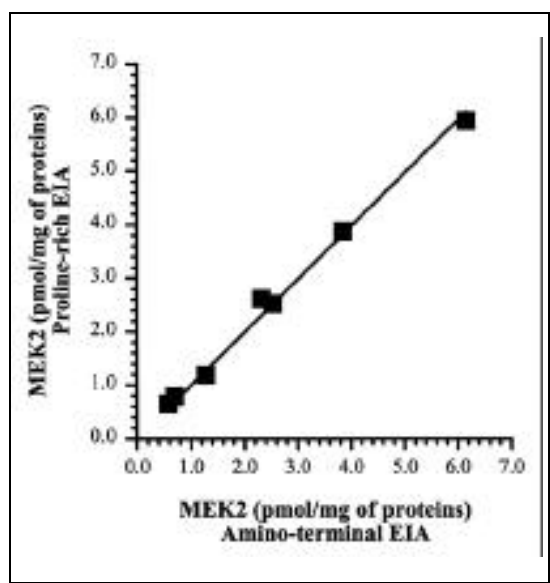

Figure 4. Concentrations of MEK2 measured in different cell lines by the amino-terminal and proline-rich EIA methods. Results obtained by both assays correlate. tion of the expression of MEK2 but also used to define its role in different chronic diseases such as atherosclerosis, cardiac hypertrophy (3) and cancer. This assay could be used to examine MEK2 expression in small tumor biopsies. Interestingly, a recent study has reported that MEK is overexpressed in approximately one-half of renal cell carcinomas (16). However, that overexpression is nonspecific for MEK2, a similar observation was also made for cdc25 phosphatase and cyclins D1 and $\mathrm{E}$ in human cancers $(7,11)$.

In conclusion, we have successfully used the Dig-anti-Dig system for the quantification of the intracellular protein kinase MEK2. Although this methodology cannot replace the measurement of enzyme activity, it nonetheless represents an improved analytical approach when compared to semiquantitative immunoblottings. This reliable and sensitive analytical approach could be adapted for the quantitative assessment of other protein kinases or intracellular signaling proteins.

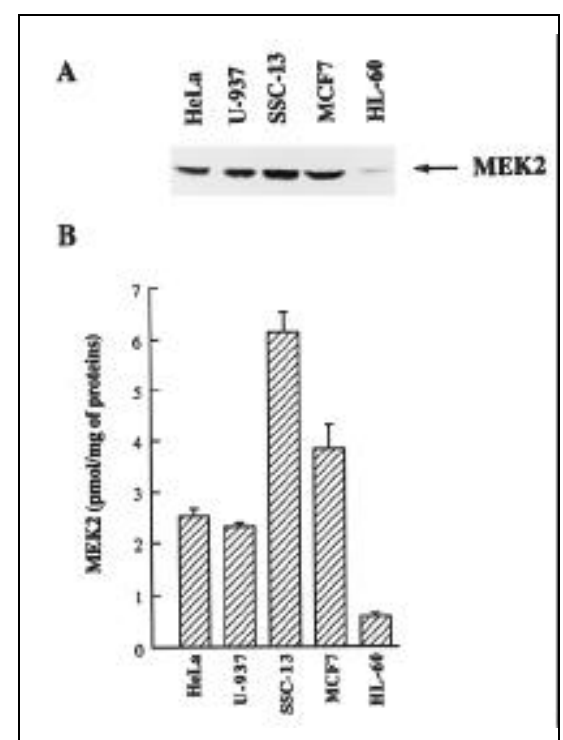

Figure 5. (A) Immunoblot analysis of MEK2 expression. Total lysates from indicated human cell lines were prepared, and equal amounts of proteins were resolved on a $10 \%$ acrylamide gel and transferred to nitrocellulose membrane. The membrane was probed with a specific anti-MEK2 monoclonal antibody, and the proteins were visualized by chemiluminescence detection. The position of MEK2 is indicated by an arrow. (B) Concentrations of MEK2 determined by the amino-terminal EIA. The amino-terminal EIA was applied to the indicated human cell lines. 


\section{ACKNOWLEDGMENTS}

We thank Edith Giasson for technical assistance and Elisabeth Pérès for preparation of the figures with gel setting. We also thank Dr. Peter Tijssen for his helpful and constructive criticism of the manuscript. This work was supported by a grant from the Medical Research Council of Canada to A.A. and from the Cancer Research Society to S.M. and R.M. S.M. is a scholar of the Medical Research Council of Canada.

\section{REFERENCES}

1.Adam, A., J. Rojas, J. Pretel, L. Martinez and H. Ong. 1996. Labelling of haptenic drug with digoxigenin for competitive immunoassay: its application to lesopitron, a new anxiolytic agent. J. Pharm. Biomed. Anal. 15:1319.

2.Allain, F., C. Boutillon, C. Mariller and G. Spik. 1995. Selective assay for CyPA and $\mathrm{CyPB}$ in human blood using highly specific anti-peptide antibodies. J. Immunol. Methods 178:113-120

3.Bogoyevitch, M.A. and P.H. Sugden. 1996. The role of protein kinases in the adaptational growth of the heart. Int. J. Biochem. Cell. Biol. 28:1-12.

4.Brott, B.K., A. Alessandrini, D.A. Largaespada, N.G. Copeland, N.A. Jenkins, C.M. Crews and R.L. Erikson. 1993. MEK2 is a kinase related to MEK1 and is differentially expressed in murine tissues. Cell Growth Differ. 4:921-929.

5.Cano, E. and L.C. Mahadevan. 1995. Parallel signal processing among mammalian MAPKs. Trends Biochem. Sci. 20:117-122.

6.Cobb, M.H. and E.J. Goldsmith. 1995. How MAP kinases are regulated. J. Biol. Chem. 270:14843-14846.

7.Cordon-Cardo, C. 1995. Mutation of cell cycle regulators. Biological and clinical implications for human neoplasia. Am. J. Pathol. 147:545-560.

8.Crowther, J.R. 1995. ELISA: theory and practice, p. 119-130. In J.M. Walker (Ed.), Methods in Molecular Biology, Vol. 42. Humana Press, Totowa, NJ.

9.Décarie, A., G. Drapeau, J. Closset, R. Couture and A. Adam. 1994. Development of digoxigenin-labeled peptide: application to chemiluminoenzyme immunoassay of bradykinin in inflamed tissues. Peptides 15:511-518.

10.Drapeau, G., R. Audet, L. Levesque, D. Godin and F. Marceau. 1993. Development and in vivo evaluation of metabolically resistant antagonists of B1 receptors for kinins. J. Pharmacol. Exp. Ther. 266:192-199.

11.Galaktionov, K., A.K. Lee, J. Eckstein, G. Draetta, J. Meckler, M. Loda and D. Beach. 1995. CDC25 phosphatases as potential human oncogenes. Science 269:1575-1577.

12.Heuer, K.H., J.P. Mackay, P. Podzebenko, N.P.S. Bains, A.S. Weiss, G.F. King and S.B.
Easterbrook-Smith. 1996. Development of a sensitive peptide-based immunoassay: application to detection of the Jun and Fos oncoproteins. Biochemistry 35:9069-9075.

13.Kessler, C. 1991. The digoxigenin:anti-digoxigenin (DIG) technology - a survey on the concept and realization of a novel bioanalytical indicator system. Mol. Cell. Probes 5:161205.

14.L'Allemain, G. 1994. Deciphering the MAP kinase pathway. Prog. Growth Factor Res. 5:291-334.

15.Morais, R., P. Desjardins, C. Turmel and K. Zinkewich-Péotti. 1988. Development and characterization of continuous avian cell lines depleted of mitochondrial DNA. In Vitro Cell. Dev. Biol. 24:649-658.

16.Oka, H., Y. Chatani, R. Hoshino, O. Ogawa, Y. Kakehi, T. Terachi, Y. Okada, M. Kawaichi, M. Kohno and O. Yoshida. 1995. Constitutive activation of mitogen-activated protein (MAP) kinases in human renal cell carcinoma. Cancer Res. 55:4182-4187.

17.Peterson, G.L. 1983. Determination of total protein. Methods Enzymol. 91:95-119.

18.Raymond, P., G. Drapeau, R. Raut, R. Audet, F. Marceau, H. Ong and A. Adam. 1995. Quantification of des-Arg9-bradykinin using a chemiluminescence enzyme immunoassay: application to its kinetic profile during plasma activation. J. Immunol. Methods 180:247-257.

19.Seger, R. and E.G. Krebs. 1995. The MAPK signaling cascade. FASEB J. 9:726-735.

20.Wu, J., J.K. Harrison, P. Dent, K.R. Lynch, M.J. Weber and T.W. Sturgill. 1993. Identification and characterization of a new mammalian mitogen-activated protein kinase kinase, MKK2. Mol. Cell. Biol. 13:4539-4548.

21.Zheng, C.-F. and K.-L. Guan. 1993. Cloning and characterization of two distinct human extracellular signal-regulated kinase activator kinases, MEK1 and MEK2. J. Biol. Chem. 268:11435-11439.

Received 2 May 1997; accepted 15 July 1997.

Address correspondence to:

Dr. Albert Adam

Faculté de pharmacie, Université de Montréal 2900, Boul. Édouard-Montpetit C.P. 6128, Succursale Centre-ville

Montréal, QC H3C 3J7, Canada

Internet: adama@ere.umontreal.ca 